\title{
Diuretic Effects of Sodium Glucose Cotransporter 2 Inhibitors and Their Influence on the Renin-Angiotensin System
}

\author{
Tuba M. Ansary ${ }^{\mathbb{D}}$, Daisuke Nakano and Akira Nishiyama * \\ Department of Pharmacology, Faculty of Medicine, Kagawa University, 1750-1 Ikenobe, Miki-cho, Kita-gun, \\ Kagawa 761-0793, Japan; tubapsy@med.kagawa-u.ac.jp (T.M.A.); dnakano@med.kagawa-u.ac.jp (D.N.) \\ * Correspondence: akira@med.kagawa-u.ac.jp; Tel.: +81-87-891-2125; Fax: +81-87-891-2126
}

Received: 4 January 2019; Accepted: 29 January 2019; Published: 1 February 2019

check for updates

\begin{abstract}
The renin-angiotensin system (RAS) plays an important role in regulating body fluids and blood pressure. However, inappropriate activation of the RAS contributes to the pathogenesis of cardiovascular and renal diseases. Recently, sodium glucose cotransporter 2 (SGLT2) inhibitors have been used as anti-diabetic agents. SGLT2 inhibitors induce glycosuria and improve hyperglycemia by inhibiting urinary reabsorption of glucose. However, in the early stages of treatment, these inhibitors frequently cause polyuria and natriuresis, which potentially activate the RAS. Nevertheless, the effects of SGLT2 inhibitors on RAS activity are not straightforward. Available data indicate that treatment with SGLT2 inhibitors transiently activates the systemic RAS in type 2 diabetic patients, but not the intrarenal RAS. In this review article, we summarize current evidence of the diuretic effects of SGLT2 inhibitors and their influence on RAS activity.
\end{abstract}

Keywords: renin-angiotensin system (RAS); sodium glucose cotransporter 2 (SGLT2) inhibitor; diuretic effect; natriuresis; type 2 diabetes

\section{Introduction}

Sodium glucose cotransporter 2 (SGLT2) inhibitors are a relatively new class of antidiabetic drugs. Four SGLT2 inhibitors—canagliflozin, dapagliflozin, empagliflozin, and ertugliflozin—are currently approved by the US Food and Drug Administration (FDA) as glucose-lowering drugs. Two more SGLT2 inhibitors, sotagliflozin and bexagliflozin, are currently in phase III clinical trials for type 2 diabetes. In Japan, three more SGLT2 inhibitors-ipragliflozin, luseogliflozin, and tofogliflozin-have been approved [1]. A few different properties among the SGLT2 inhibitors have been reported. For example, in vitro studies have shown that canagliflozin is less selective between SGLT2 and SGLT1 than other SGLT2 inhibitors [2]. Pharmacokinetics studies have also indicated that ipragliflozin and luseogliflozin show rapid drug distribution in the kidney [3].

In healthy individuals, filtered glucose is fully reabsorbed at the proximal tubules and no glucose is detected in the urine. SGLT2, a low-affinity and high-capacity glucose transporter, is located in the convoluted proximal tubule and responsible for reabsorbing around $90 \%$ of filtered glucose in the kidney [4]. In type 2 diabetes, the expression and activity of SGLT2 are significantly increased, which may lead to a further increase in glucose reabsorption and thus contribute to hyperglycemia [5]. Treatment with SGLT2 inhibitors improves hyperglycemia by inhibiting reabsorption of filtered glucose, thereby increasing glycosuria [6,7]. SGLT2 inhibitors reduce the capacity for renal glucose reabsorption by $30-50 \%$ [8], but $36-44 \%$ of glucose reabsorption is still maintained under SGLT2 deficiency $[9,10]$. Treatment with SGLT2 inhibitors provides an insulin-independent reduction in hemoglobin A1c levels with potential additional benefits, such as body weight loss, uricosuria, natriuresis, and osmotic diuresis $[11,12]$. 
The risk of cardiovascular events and renal diseases is greater in diabetic patients, leading to increased risk of mortality [13]. Recently, the EMPA-REG OUTCOME study and CANVAS program have shown that the selective SGLT2 inhibitors, empagliflozin and canagliflozin, significantly decrease the risk of cardiovascular death or hospitalized heart failure in type 2 diabetic patients who suffer a high risk of cardiovascular diseases $[14,15]$. The mechanisms behind this beneficial outcome are not well understood, although both empagliflozin and canagliflozin result in reduced blood pressure. Notably, the reduced risk of heart failure occurred during the early phase of the follow-up period, suggesting the possible role of hemodynamic changes induced by SGLT2 inhibitors. Indeed, clinical studies have shown that SGLT2 inhibitors initially cause natriuresis after treatment begins [16-19]. SGLT2 inhibitors do not have long-term natriuretic effects in type 2 diabetes patients, and the literature on the mechanisms of the transient natriuretic effects of SGLT2 inhibitors is limited. It has been suggested that there is a compensatory mechanism. For example, several sodium transporters may be activated to increase sodium uptake in the tubule in response to the mild natriuresis caused by SGLT2 inhibitors [20]. It is also possible that the diuresis, natriuresis, and associated body fluid loss induced by SGLT2 inhibitors activate the renin-angiotensin system (RAS). Therefore, this review aims to discuss the diuretic effects of SGLT2 inhibitors and their influence on the activity of the RAS.

\section{Diuretic Effects of SGLT2 Inhibitors}

\subsection{Changes in Urine Volume and Urinary Sodium Excretion}

The diuretic actions of SGLT2 inhibitors presumably play an important role in cardioprotection, as shown in the EMPA-REG OUTCOME study and the CANVAS program. SGLT2 inhibitors have acutely caused an increase in urinary sodium excretion in non-diabetic rats [21] and in diabetic rats [22,23]. In type 2 diabetic patients, increased urinary sodium excretion has been observed during the early phase of treatment with canagliflozin $[16,18,19]$ and empagliflozin [24]. Antihypertensive effects found in the EMPA-REG OUTCOME study and the CANVAS program are probably due to natriuresis induced by the SGLT2 inhibitors [14,15]. Notably, dapagliflozin has been shown to reduce plasma volume in a similar way to thiazide diuretics, but dapagliflozin has a more enduring diuretic effect than other diuretics [25]. The plasma volume reduction is accompanied by an increase in hematocrit, which has been observed in patients treated with SGLT2 inhibitors $[8,26]$. Likewise, empagliflozin-treated patients have shown a hematocrit of approximately $5 \%$ higher than the placebo-treated patients [14]. Mathematical models have indicated that SGLT2 inhibitors can result in interstitial fluid clearance without changing the intravascular volume by osmotic diuresis [27].

Over the last decade, sodium accumulation in tissues has received growing attention as a marker of volume-expanded states [28]. Sodium concentrations in the skin and muscles are reportedly positively correlated with the risk of cardiovascular diseases and blood pressure in chronic kidney disease [29,30]. Interestingly, chronic treatment with dapagliflozin significantly reduces sodium concentrations in the skin of type 2 diabetic patients [31]. These data support the hypothesis that SGLT2 inhibitors decrease the sodium concentration in interstitial fluid and thus reduce the risk of cardiovascular diseases.

Clinical studies have shown that canagliflozin increases urine volume in type 2 diabetic patients during the first few days of treatment [18,32-36]. In Japanese type 2 diabetic patients, empagliflozin increases urine volume initially [37]. Similar observations have also been found in type 2 diabetic patients treated with dapagliflozin [38]. Collectively, data consistently indicate that treatment with SGLT2 inhibitors results in natriuresis that is associated with glycosuria. However, these diuretic effects appear to be transient based on the available data in patients with type 2 diabetes. The effects of SGLT2 inhibitors on urine volume and urinary sodium excretion are summarized in Table 1. 
Table 1. SGLT2 inhibitor-induced changes in urine volume and urinary sodium excretion.

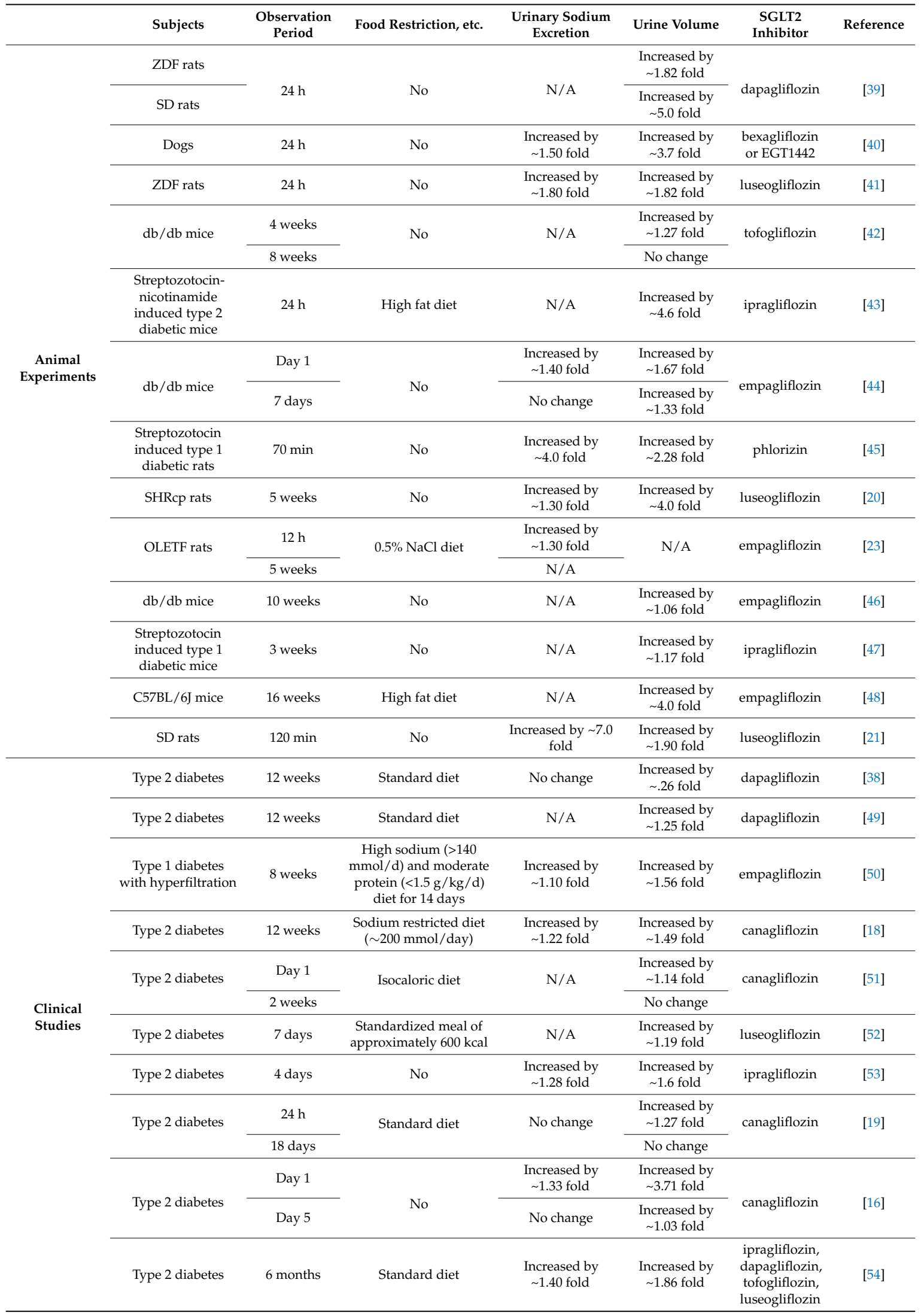

SGLT2, sodium glucose cotransporter 2; ZDF, zucker diabetic fatty; SD, sprague dawley; SHRcp, metabolic syndrome SHR/NDmcr-cp (+/+); OLETF, otsuka long-evans tokushima fatty; N/A, not available. 


\subsection{Changes in Tubular Functions}

It has been indicated that transport of water and sodium is activated in diabetes to compensate loss of water and sodium [55]. In type 1 diabetic patients, expression of renal sodium and water channels, such as sodium-hydrogen exchanger (NHE3), $\mathrm{Na}-\mathrm{Cl}$ cotransporter (NCC), epithelial sodium channel (ENaC), $\mathrm{Na}-\mathrm{K}-2 \mathrm{Cl}$ cotransporter (NKCC2), aquaporin 2, and urea transporters is significantly increased [56-58]. Under hyperglycemic conditions, human exfoliated proximal tubular epithelial cells isolated from type 2 diabetic patients have a threefold increase of glucose uptake along with increased expression and activity of SGLT2 [7]. The expression of distal nephron sodium transporter proteins, such as NKCC2, NCC and ENaC, is also increased in type 2 diabetes, resulting in increased sodium reabsorption $[59,60]$. Studies have shown that total sodium reabsorption by SGLT2 is significantly increased in diabetes [61].

Microperfusion studies have also shown that SGLT2 functionally interact and colocalize with NHE3 in the proximal tubule and that inhibition of SGLT2 with phlorizin can inhibit NHE3-dependent bicarbonate reabsorption [62]. Moreover, phosphorylation of NHE3, which associates with its reduced activity, is increased in type 1 diabetic Akita mice treated with empagliflozin [63,64]. Conversely, another study has shown that treatment with luseogliflozin increases NHE3 and NCC protein expression in the renal cortical tissues of spontaneously hypertensive rats [20], probably owing to the compensatory increase in solute delivery in the tubules by the SGLT2 inhibitor. Thus, the effects of SGLT2 inhibitors on the function of sodium transporters appear to be controversial.

Dapagliflozin has been shown to reduce proteinuria in an experimental model of non-diabetic proteinuric nephropathy without affecting glomerular filtration rate (GFR) [65]. Studies in $\mathrm{db} / \mathrm{db}$ mice have also shown that hyperglycemia increases kidney volume without enlarging glomeruli and that treatment with SGLT2 inhibitors causes glomerular hypertrophy, glomeruli redistribution, and reduced kidney volume, with no effects on GFR [66]. Similarly, acute administration of luseogliflozin has not changed GFR in non-diabetic rats [21]. However, empagliflozin has resulted in a significant decrease in GFR in Akita mice [67]. Collectively, while SGLT2 inhibitors frequently decrease GFR in diabetic patients, this effect is not consistently observed in diabetic and non-diabetic animals. However, the active site for the SGLT2 inhibitors and molecular mechanisms responsible for the diuresis and natriuresis induced has not been determined yet.

\section{Effects of SGLT2 Inhibitors on RAS Activity}

Inappropriate activation of the RAS is a critical factor in the pathogenesis of cardiovascular and renal diseases associated with diabetes [13]. In response to stimuli such as reduced renal perfusion pressure and sodium load at the distal tubules, renin release from the juxtaglomerular cells is significantly increased [68]. SGLT2 inhibitors can cause natriuresis, at least in the early phase of treatment, resulting in systemic RAS activation. Furthermore, the intrarenal RAS is sometimes activated to compensate for the sodium and water loss caused by SGLT2 inhibitors [69]. To monitor the RAS activity, several biomarkers have been used, including plasma renin activity (PRA), plasma aldosterone concentration, urinary angiotensinogen (AGT) and angiotensin II (Ang II) levels [70-73]. Effects of SGLT2 inhibitors on RAS parameters are summarized in Table 2 and discussed in detail later. 
Table 2. Relationship between SGLT2 inhibitor-induced changes in urine volume and urinary sodium excretion and RAS parameters.

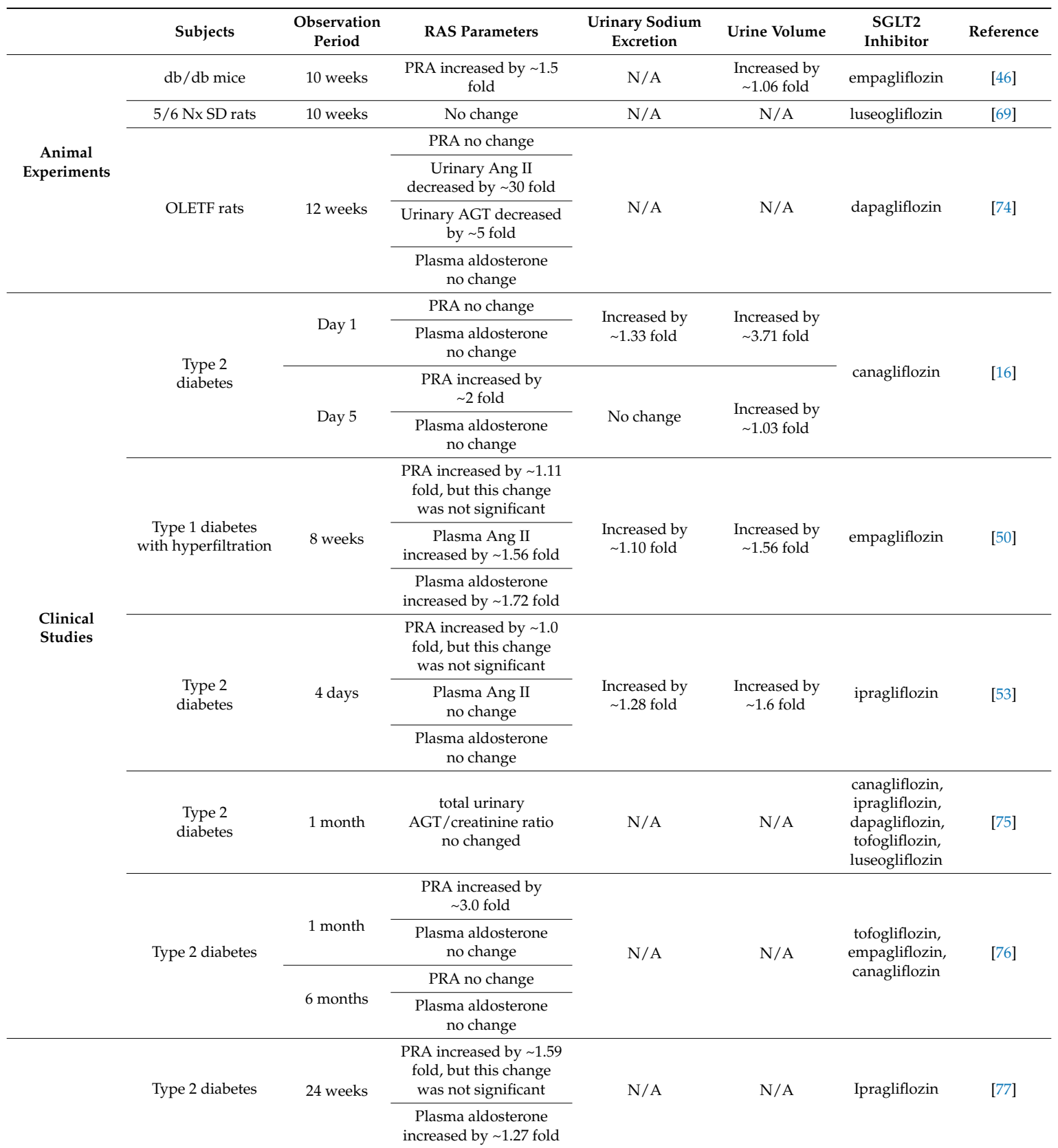

SGLT2, sodium glucose cotransporter 2; RAS, renin angiotensin system; PRA, plasma renin activity; Nx, nephrectomy; SD, sprague dawley; OLETF, otsuka long-evans tokushima fatty; Ang II, angiotensin II; AGT, angiotensinogen.

\subsection{Systemic RAS}

In patients with essential hypertension, treatment with diuretics often elevates PRA, probably because of body fluid loss [78,79]. Similarly, SGLT2 inhibitor-induced osmotic diuresis, natriuresis, and the associated reductions in extracellular volume and blood pressure might activate the systemic RAS in diabetes $[25,46,50,80]$. Type 2 diabetic $\mathrm{db} / \mathrm{db}$ mice have shown higher PRA than the non-diabetic counterparts, but treatment with empagliflozin has not changed the increased PRA [46]. In Otsuka Long-Evans Tokushima fatty (OLETF) rats, a type 2 diabetic model, PRA and serum aldosterone levels are significantly increased and remain unchanged upon chronic treatment with dapagliflozin [74]. Similarly, the levels of systemic RAS components do not change significantly after 10 weeks of SGLT2 
inhibitor treatment in a chronic kidney disease rat model [69]. In clinical studies, dapagliflozin has increased PRA and serum aldosterone after 12 weeks of treatment in type 2 diabetic patients [25]. Conversely, PRA did not change significantly after chronic treatment of type 2 diabetic patients with SGLT2 inhibitors in another study [76]. Increases in systemic RAS parameters can be explained by the compensatory mechanism in response to volume reduction by SGLT2 inhibitors. However, available clinical data have shown that the plasma aldosterone level did not significantly change by treatment with an SGLT2 inhibitor [74]. This may be because aldosterone production is stimulated not only by Ang II, but also by other factors, such as adrenocorticotropic hormone and potassium. Furthermore, the aldosterone level is affected by sampling conditions because it is driven by the circadian rhythm [81]. Moreover, as mentioned before, the diuretic action of SGLT2 inhibitors is usually transient and is no longer observed a few days after treatment [16-19,82,83].

Furthermore, SGLT2 inhibitors improve the circadian rhythm of sympathetic nerve activity [84,85], while their effects on sympathetic nerve activity may also influence the activity of the systemic RAS.

\subsection{Intrarenal RAS}

Studies have indicated that the liver is the source of AGT in both plasma and kidneys [86]. However, it has also been shown that AGT is locally expressed in proximal tubules [87]. As shown in Figure 1, treatment with an SGLT2 inhibitor may affect intrarenal AGT production via changes in glucose levels. However, it is unclear whether SGLT2 inhibitors influence systemic AGT filtration at the glomerulus. It has been shown that AGT plays a predominant role in the regulation of intrarenal RAS $[68,72]$. Administration of high glucose $(15 \mathrm{mM})$ has significantly increased AGT mRNA levels in cultured human proximal tubular cells [88]. Therefore, a reduction in blood sugar levels with SGLT2 inhibitors may decrease AGT production in the early proximal tubule. Conversely, SGLT2 inhibition can increase glucose delivery to the distal proximal tubule, and, therefore, AGT production may be stimulated. Different effects of SGLT2 inhibitors on AGT production between early and distal proximal tubules may explain the inconsistent data regarding the responses of intrarenal RAS to SGLT2 inhibitors. Type 2 diabetic OLETF rats have shown augmented intrarenal RAS [89], and treatment with dapagliflozin significantly lowered the urinary Ang II and AGT levels [74]. In patients with type 2 diabetes, treatment with SGLT2 inhibitors also tended to decrease urinary AGT excretion, although these changes were not statistically significant [75]. In contrast, in patients with type 1 diabetes, treatment with empagliflozin significantly increased the urinary AGT/creatinine ratio [50]. Importantly, several studies have indicated a higher urinary AGT/creatinine ratio in patients with type 2 diabetes than in patients with type 1 diabetes $[90,91]$. Thus, the basal activity of intrarenal RAS may influence the SGLT2 inhibitor's effect on it. Another important point is that diabetic patients are frequently medicated with RAS inhibitors, such as angiotensin-converting enzyme inhibitors and angiotensin receptor blockers [14], which may affect the changes in intrarenal RAS in type 2 diabetes. Nevertheless, we cannot find any evidence that SGLT2 inhibitors actually activate the intrarenal RAS in type 2 diabetes. The possible mechanisms by which SGLT2 inhibitors influence the systemic and renal RAS are illustrated in Figure 1. 


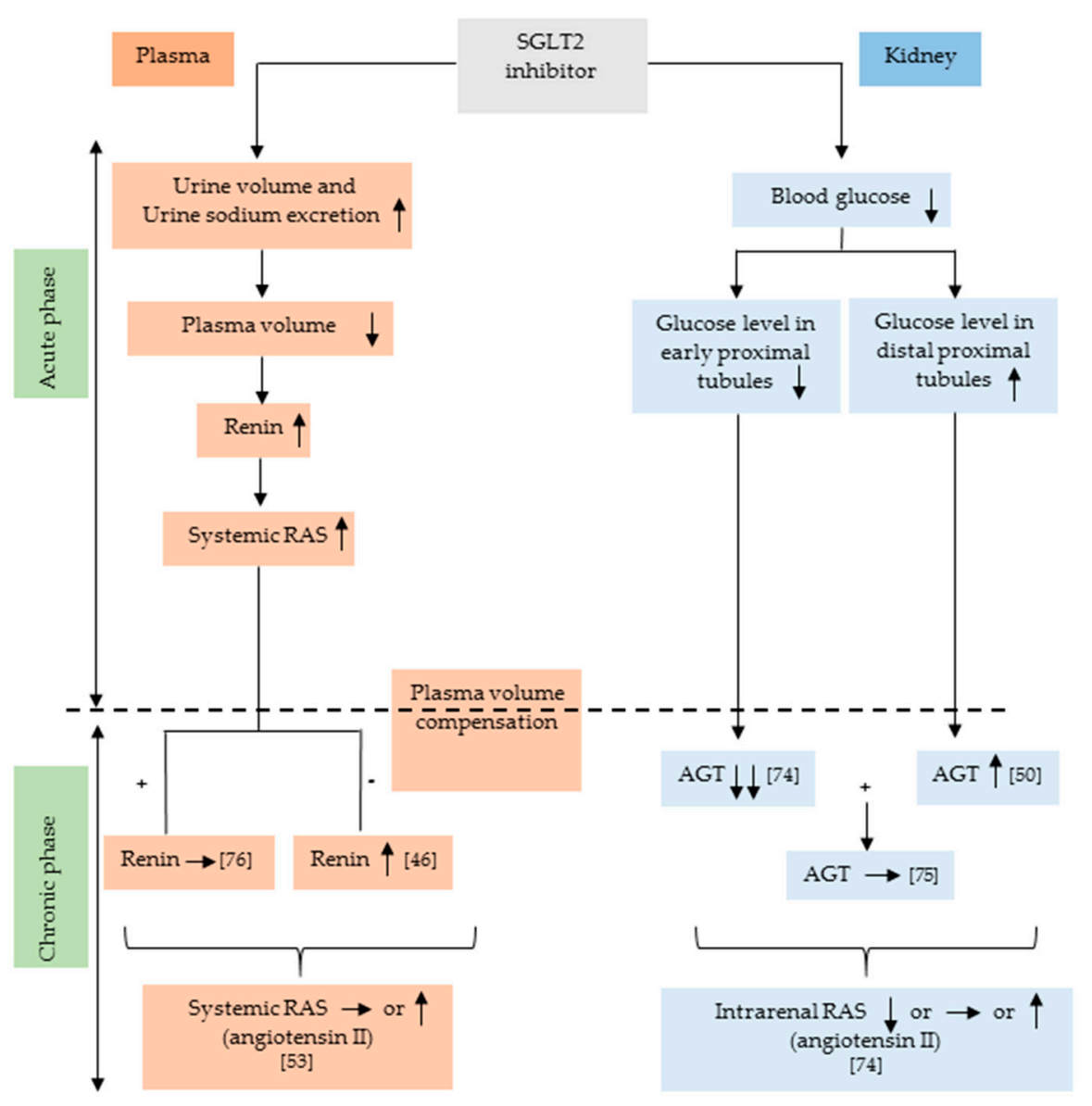

Figure 1. Possible mechanisms by which SGLT2 inhibitors influence the systemic and intrarenal RAS. SGLT2 inhibitors transiently increase plasma renin activity acutely through osmotic diuresis. Meanwhile, SGLT2 inhibitors decrease renal AGT expression by reducing glucose levels in the kidney. However, SGLT2 inhibitors can increase the glucose load in distal proximal tubule and that might increase the AGT production. SGLT2, sodium-glucose cotransporter 2; RAS, renin-angiotensin system; AGT, angiotensinogen. $\uparrow$, increase; $\downarrow$, decrease; $\rightarrow$, no change; + , in case of plasma volume compensation; - , in case of no plasma volume compensation.

\section{Conclusions}

The findings that the beneficial effects of SGLT2 inhibitors on cardiovascular outcomes are observed in the early phase of treatment support the direct diuretic and hemodynamic effects of SGLT2 inhibitors. The transient diuretic effects potentially lead to systemic RAS activation. However, the association between SGLT2 inhibitors and systemic RAS activation is not straightforward. Furthermore, data have indicated that chronic treatment with SGLT2 inhibitors does not activate the intrarenal RAS in type 2 diabetic patients. Future work is thus needed to develop stable biomarkers for both the systemic and intrarenal RAS. To contribute to this unmet need, we have recently developed new assay systems for measuring stable PRA and intrarenal renin activity by calculating the ratio of (total AGT-intact AGT)/intact AGT in plasma and urine respectively $[68,69,92]$.

Author Contributions: T.M.A. wrote the manuscript and T.M.A. and A.N. scrutinized previous clinical and experimental data. A.N. and D.N. revised the manuscript critically. All authors have read and approved the final version of the manuscript.

Funding: A.N. has received research funding from Boehringer Ingelheim, Taisho-Toyama and Daiichi-Sankyo. A.N. has also received honoraria for educational meetings conducted on behalf of Boehringer Ingelheim and Taisho-Toyama.

Acknowledgments: We thank Amy Tong from Edanz Group for editing the English draft of this manuscript. 
Conflicts of Interest: The authors declare no conflict of interest. The funders had no role in the study design, data collection and analysis, decision to publish, or preparation of the manuscript.

\section{References}

1. Aguillón, A.R.; Mascarello, A.; Segretti, N.D.; de Azevedo, H.F.Z.; Guimaraes, C.R.W.; Miranda, L.S.M.; de Souza, R.O.M.A. Synthetic Strategies toward SGLT2 Inhibitors. Org. Process Res. Dev. 2018, 22, 467-488. [CrossRef]

2. Hsia, D.S.; Grove, O.; Cefalu, W.T. An update on sodium-glucose co-transporter-2 inhibitors for the treatment of diabetes mellitus. Curr. Opin. Endocrinol. Diabetes Obes. 2017, 24, 73-79. [CrossRef] [PubMed]

3. Tahara, A.; Takasu, T.; Yokono, M.; Imamura, M.; Kurosaki, E. Characterization and comparison of sodium-glucose cotransporter 2 inhibitors: Part 2. Antidiabetic effects in type 2 diabetic mice. J. Pharmacol. Sci. 2016, 131, 198-208. [CrossRef] [PubMed]

4. Ferrannini, E.; Solini, A. SGLT2 inhibition in diabetes mellitus: Rationale and clinical prospects. Nat. Rev. Endocrinol. 2012, 8, 495-502. [CrossRef] [PubMed]

5. DeFronzo, R.A.; Davidson, J.A.; Del Prato, S. The role of the kidneys in glucose homeostasis: A new path towards normalizing glycaemia. Diabetes Obes. Metab. 2012, 14, 5-14. [CrossRef] [PubMed]

6. Liu, J.J.; Lee, T.; DeFronzo, R.A. Why Do SGLT2 inhibitors inhibit only 30-50\% of renal glucose reabsorption in humans? Diabetes 2012, 61, 2199-2204. [CrossRef] [PubMed]

7. Rahmoune, H.; Thompson, P.W.; Ward, J.M.; Smith, C.D.; Hong, G.; Brown, J. Glucose transporters in human renal proximal tubular cells isolated from the urine of patients with non-insulin-dependent diabetes. Diabetes 2005, 54, 3427-3434. [CrossRef]

8. Abdul-Ghani, M.A.; DeFronzo, R.A.; Norton, L. Novel hypothesis to explain why SGLT2 inhibitors inhibit only 30-50\% of filtered glucose load in humans. Diabetes 2013, 62, 3324-3328. [CrossRef]

9. Vallon, V.; Platt, K.A.; Cunard, R.; Schroth, J.; Whaley, J.; Thomson, S.C.; Koepsell, H.; Rieg, T. SGLT2 mediates glucose reabsorption in the early proximal tubule. J. Am. Soc. Nephrol. 2011, 22, 104-112. [CrossRef]

10. Rieg, T.; Masuda, T.; Gerasimova, M.; Mayoux, E.; Platt, K.; Powell, D.R.; Thomson, S.C.; Koepsell, H.; Vallon, V. Increase in SGLT1-mediated transport explains renal glucose reabsorption during genetic and pharmacological SGLT2 inhibition in euglycemia. Am. J. Physiol. Ren. Physiol. 2014, 306, F188-F193. [CrossRef]

11. Heerspink, H.J.; Perkins, B.A.; Fitchett, D.H.; Husain, M.; Cherney, D.Z. Sodium Glucose Cotransporter 2 Inhibitors in the Treatment of Diabetes Mellitus: Cardiovascular and Kidney Effects, Potential Mechanisms, and Clinical Applications. Circulation 2016, 134, 752-772. [CrossRef] [PubMed]

12. Lytvyn, Y.; Skrtic, M.; Yang, G.K.; Yip, P.M.; Perkins, B.A.; Cherney, D.Z. Glycosuria-mediated urinary uric acid excretion in patients with uncomplicated type 1 diabetes mellitus. Am. J. Physiol. Ren. Physiol. 2015, 308, F77-F83. [CrossRef] [PubMed]

13. Yamazaki, D.; Hitomi, H.; Nishiyama, A. Hypertension with diabetes mellitus complications. Hypertens. Res. 2018, 41, 147-156. [CrossRef] [PubMed]

14. Zinman, B.; Wanner, C.; Lachin, J.M.; Fitchett, D.; Bluhmki, E.; Hantel, S.; Mattheus, M.; Devins, T.; Johansen, O.E.; Woerle, H.J.; et al. Empagliflozin, Cardiovascular Outcomes, and Mortality in Type 2 Diabetes. N. Engl. J. Med. 2015, 373, 2117-2128. [CrossRef] [PubMed]

15. Radholm, K.; Figtree, G.; Perkovic, V.; Solomon, S.D.; Mahaffey, K.W.; de Zeeuw, D.; Fulcher, G.; Barrett, T.D.; Shaw, W.; Desai, M.; et al. Canagliflozin and Heart Failure in Type 2 Diabetes Mellitus: Results From the CANVAS Program (Canagliflozin Cardiovascular Assessment Study). Circulation 2018. [CrossRef] [PubMed]

16. Tanaka, H.; Takano, K.; Iijima, H.; Kubo, H.; Maruyama, N.; Hashimoto, T.; Arakawa, K.; Togo, M.; Inagaki, N.; $\mathrm{Kaku}, \mathrm{K}$. Factors Affecting Canagliflozin-Induced Transient Urine Volume Increase in Patients with Type 2 Diabetes Mellitus. Adv. Ther. 2017, 34, 436-451. [CrossRef] [PubMed]

17. Rajasekeran, H.; Lytvyn, Y.; Cherney, D.Z. Sodium-glucose cotransporter 2 inhibition and cardiovascular risk reduction in patients with type 2 diabetes: The emerging role of natriuresis. Kidney Int. 2016, 89, 524-526. [CrossRef] [PubMed]

18. Sha, S.; Polidori, D.; Heise, T.; Natarajan, J.; Farrell, K.; Wang, S.S.; Sica, D.; Rothenberg, P.; Plum-Morschel, L. Effect of the sodium glucose co-transporter 2 inhibitor canagliflozin on plasma volume in patients with type 2 diabetes mellitus. Diabetes Obes. Metab. 2014, 16, 1087-1095. [CrossRef] [PubMed] 
19. Iijima, H.; Kifuji, T.; Maruyama, N.; Inagaki, N. Pharmacokinetics, Pharmacodynamics, and Safety of Canagliflozin in Japanese Patients with Type 2 Diabetes Mellitus. Adv. Ther. 2015, 32, 768-782. [CrossRef] [PubMed]

20. Rahman, A.; Kittikulsuth, W.; Fujisawa, Y.; Sufiun, A.; Rafiq, K.; Hitomi, H.; Nakano, D.; Sohara, E.; Uchida, S.; Nishiyama, A. Effects of diuretics on sodium-dependent glucose cotransporter 2 inhibitor-induced changes in blood pressure in obese rats suffering from the metabolic syndrome. J. Hypertens. 2016, 34, 893-906. [CrossRef]

21. Ansary, T.M.; Fujisawa, Y.; Rahman, A.; Nakano, D.; Hitomi, H.; Kobara, H.; Masaki, T.; Titze, J.M.; Kitada, K.; Nishiyama, A. Responses of renal hemodynamics and tubular functions to acute sodium-glucose cotransporter 2 inhibitor administration in non-diabetic anesthetized rats. Sci. Rep. 2017, 7, 9555. [CrossRef]

22. Thomson, S.C.; Rieg, T.; Miracle, C.; Mansoury, H.; Whaley, J.; Vallon, V.; Singh, P. Acute and chronic effects of SGLT2 blockade on glomerular and tubular function in the early diabetic rat. Am. J. Physiol. Regul. Integr. Comp. Physiol. 2012, 302, R75-R83. [CrossRef]

23. Takeshige, Y.; Fujisawa, Y.; Rahman, A.; Kittikulsuth, W.; Nakano, D.; Mori, H.; Masaki, T.; Ohmori, K.; Kohno, M.; Ogata, H.; et al. A sodium-glucose co-transporter 2 inhibitor empagliflozin prevents abnormality of circadian rhythm of blood pressure in salt-treated obese rats. Hypertens. Res. 2016, 39, 415-422. [CrossRef]

24. Ferrannini, E.; Baldi, S.; Frascerra, S.; Astiarraga, B.; Barsotti, E.; Clerico, A.; Muscelli, E. Renal Handling of Ketones in Response to Sodium-Glucose Cotransporter 2 Inhibition in Patients With Type 2 Diabetes. Diabetes Care 2017, 40, 771-776. [CrossRef] [PubMed]

25. Lambers Heerspink, H.J.; de Zeeuw, D.; Wie, L.; Leslie, B.; List, J. Dapagliflozin a glucose-regulating drug with diuretic properties in subjects with type 2 diabetes. Diabetes Obes. Metab. 2013, 15, 853-862. [CrossRef]

26. Reed, J.W. Impact of sodium-glucose cotransporter 2 inhibitors on blood pressure. Vasc. Health Risk Manag. 2016, 12, 393-405. [CrossRef] [PubMed]

27. Verma, S.; McMurray, J.J.V. SGLT2 inhibitors and mechanisms of cardiovascular benefit: A state-of-the-art review. Diabetologia 2018, 61, 2108-2117. [CrossRef]

28. Lytvyn, Y.; Bjornstad, P.; Udell, J.A.; Lovshin, J.A.; Cherney, D.Z.I. Sodium Glucose Cotransporter-2 Inhibition in Heart Failure: Potential Mechanisms, Clinical Applications, and Summary of Clinical Trials. Circulation 2017, 136, 1643-1658. [CrossRef]

29. Titze, J. A different view on sodium balance. Curr. Opin. Nephrol. Hypertens. 2015, 24, 14-20. [CrossRef]

30. Schneider, M.P.; Raff, U.; Kopp, C.; Scheppach, J.B.; Toncar, S.; Wanner, C.; Schlieper, G.; Saritas, T.; Floege, J.; Schmid, M.; et al. Skin Sodium Concentration Correlates with Left Ventricular Hypertrophy in CKD. J. Am. Soc. Nephrol. 2017, 28, 1867-1876. [CrossRef]

31. Karg, M.V.; Bosch, A.; Kannenkeril, D.; Striepe, K.; Ott, C.; Schneider, M.P.; Boemke-Zelch, F.; Linz, P.; Nagel, A.M.; Titze, J.; et al. SGLT-2-inhibition with dapagliflozin reduces tissue sodium content: A randomised controlled trial. Cardiovasc. Diabetol. 2018, 17, 5. [CrossRef] [PubMed]

32. Heise, T.; Seewaldt-Becker, E.; Macha, S.; Hantel, S.; Pinnetti, S.; Seman, L.; Woerle, H.J. Safety, tolerability, pharmacokinetics and pharmacodynamics following 4 weeks' treatment with empagliflozin once daily in patients with type 2 diabetes. Diabetes Obes. Metab. 2013, 15, 613-621. [CrossRef] [PubMed]

33. Weir, M.R.; Januszewicz, A.; Gilbert, R.E.; Vijapurkar, U.; Kline, I.; Fung, A.; Meininger, G. Effect of canagliflozin on blood pressure and adverse events related to osmotic diuresis and reduced intravascular volume in patients with type 2 diabetes mellitus. J. Clin. Hypertens. (Greenwich) 2014, 16, 875-882. [CrossRef] [PubMed]

34. Bode, B.; Stenlof, K.; Sullivan, D.; Fung, A.; Usiskin, K. Efficacy and safety of canagliflozin treatment in older subjects with type 2 diabetes mellitus: A randomized trial. Hosp. Pract. (1995) 2013, 41, 72-84. [CrossRef] [PubMed]

35. Yale, J.F.; Bakris, G.; Cariou, B.; Yue, D.; David-Neto, E.; Xi, L.; Figueroa, K.; Wajs, E.; Usiskin, K.; Meininger, G. Efficacy and safety of canagliflozin in subjects with type 2 diabetes and chronic kidney disease. Diabetes Obes. Metab. 2013, 15, 463-473. [CrossRef] [PubMed]

36. Wilding, J.P.; Blonde, L.; Leiter, L.A.; Cerdas, S.; Tong, C.; Yee, J.; Meininger, G. Efficacy and safety of canagliflozin by baseline HbA1c and known duration of type 2 diabetes mellitus. J. Diabetes Complicat. 2015, 29, 438-444. [CrossRef] 
37. Yasui, A.; Lee, G.; Hirase, T.; Kaneko, T.; Kaspers, S.; von Eynatten, M.; Okamura, T. Empagliflozin Induces Transient Diuresis Without Changing Long-Term Overall Fluid Balance in Japanese Patients with Type 2 Diabetes. Diabetes Ther. 2018, 9, 863-871. [CrossRef]

38. List, J.F.; Woo, V.; Morales, E.; Tang, W.; Fiedorek, F.T. Sodium-glucose cotransport inhibition with dapagliflozin in type 2 diabetes. Diabetes Care 2009, 32, 650-657. [CrossRef]

39. Han, S.; Hagan, D.L.; Taylor, J.R.; Xin, L.; Meng, W.; Biller, S.A.; Wetterau, J.R.; Washburn, W.N.; Whaley, J.M. Dapagliflozin, a selective SGLT2 inhibitor, improves glucose homeostasis in normal and diabetic rats. Diabetes 2008, 57, 1723-1729. [CrossRef]

40. Zhang, W.; Welihinda, A.; Mechanic, J.; Ding, H.; Zhu, L.; Lu, Y.; Deng, Z.; Sheng, Z.; Lv, B.; Chen, Y.; et al. EGT1442, a potent and selective SGLT2 inhibitor, attenuates blood glucose and $\mathrm{HbA}(1 \mathrm{c})$ levels in $\mathrm{db} / \mathrm{db}$ mice and prolongs the survival of stroke-prone rats. Pharmacol. Res. 2011, 63, 284-293. [CrossRef]

41. Yamamoto, K.; Uchida, S.; Kitano, K.; Fukuhara, N.; Okumura-Kitajima, L.; Gunji, E.; Kozakai, A.; Tomoike, H.; Kojima, N.; Asami, J.; et al. TS-071 is a novel, potent and selective renal sodium-glucose cotransporter 2 (SGLT2) inhibitor with anti-hyperglycaemic activity. Br. J. Pharmacol. 2011, 164, 181-191. [CrossRef] [PubMed]

42. Nagata, T.; Fukuzawa, T.; Takeda, M.; Fukazawa, M.; Mori, T.; Nihei, T.; Honda, K.; Suzuki, Y.; Kawabe, Y. Tofogliflozin, a novel sodium-glucose co-transporter 2 inhibitor, improves renal and pancreatic function in db/db mice. Br. J. Pharmacol. 2013, 170, 519-531. [CrossRef]

43. Tahara, A.; Kurosaki, E.; Yokono, M.; Yamajuku, D.; Kihara, R.; Hayashizaki, Y.; Takasu, T.; Imamura, M.; Li, Q.; Tomiyama, H.; et al. Effects of SGLT2 selective inhibitor ipragliflozin on hyperglycemia, hyperlipidemia, hepatic steatosis, oxidative stress, inflammation, and obesity in type 2 diabetic mice. Eur. J. Pharmacol. 2013, 715, 246-255. [CrossRef] [PubMed]

44. Lin, B.; Koibuchi, N.; Hasegawa, Y.; Sueta, D.; Toyama, K.; Uekawa, K.; Ma, M.; Nakagawa, T.; Kusaka, H.; Kim-Mitsuyama, S. Glycemic control with empagliflozin, a novel selective SGLT2 inhibitor, ameliorates cardiovascular injury and cognitive dysfunction in obese and type 2 diabetic mice. Cardiovasc. Diabetol. 2014, 13, 148. [CrossRef] [PubMed]

45. O'Neill, J.; Fasching, A.; Pihl, L.; Patinha, D.; Franzen, S.; Palm, F. Acute SGLT inhibition normalizes $\mathrm{O}_{2}$ tension in the renal cortex but causes hypoxia in the renal medulla in anaesthetized control and diabetic rats. Am. J. Physiol. Ren. Physiol. 2015, 309, F227-F234. [CrossRef] [PubMed]

46. Gallo, L.A.; Ward, M.S.; Fotheringham, A.K.; Zhuang, A.; Borg, D.J.; Flemming, N.B.; Harvie, B.M.; Kinneally, T.L.; Yeh, S.M.; McCarthy, D.A.; et al. Once daily administration of the SGLT2 inhibitor, empagliflozin, attenuates markers of renal fibrosis without improving albuminuria in diabetic $\mathrm{db} / \mathrm{db}$ mice. Sci. Rep. 2016, 6, 26428. [CrossRef] [PubMed]

47. Salim, H.M.; Fukuda, D.; Yagi, S.; Soeki, T.; Shimabukuro, M.; Sata, M. Glycemic Control with Ipragliflozin, a Novel Selective SGLT2 Inhibitor, Ameliorated Endothelial Dysfunction in Streptozotocin-Induced Diabetic Mouse. Front. Cardiovasc. Med. 2016, 3, 43. [CrossRef]

48. Xu, L.; Nagata, N.; Nagashimada, M.; Zhuge, F.; Ni, Y.; Chen, G.; Mayoux, E.; Kaneko, S.; Ota, T. SGLT2 Inhibition by Empagliflozin Promotes Fat Utilization and Browning and Attenuates Inflammation and Insulin Resistance by Polarizing M2 Macrophages in Diet-induced Obese Mice. EBioMedicine 2017, 20 , 137-149. [CrossRef]

49. Wilding, J.P.; Norwood, P.; T’Joen, C.; Bastien, A.; List, J.F.; Fiedorek, F.T. A study of dapagliflozin in patients with type 2 diabetes receiving high doses of insulin plus insulin sensitizers: Applicability of a novel insulin-independent treatment. Diabetes Care 2009, 32, 1656-1662. [CrossRef]

50. Cherney, D.Z.; Perkins, B.A.; Soleymanlou, N.; Maione, M.; Lai, V.; Lee, A.; Fagan, N.M.; Woerle, H.J.; Johansen, O.E.; Broedl, U.C.; et al. Renal hemodynamic effect of sodium-glucose cotransporter 2 inhibition in patients with type 1 diabetes mellitus. Circulation 2014, 129, 587-597. [CrossRef]

51. Sha, S.; Devineni, D.; Ghosh, A.; Polidori, D.; Hompesch, M.; Arnolds, S.; Morrow, L.; Spitzer, H.; Demarest, K.; Rothenberg, P. Pharmacodynamic effects of canagliflozin, a sodium glucose co-transporter 2 inhibitor, from a randomized study in patients with type 2 diabetes. PLoS ONE 2014, 9, e110069. [CrossRef] [PubMed]

52. Sasaki, T.; Seino, Y.; Fukatsu, A.; Ubukata, M.; Sakai, S.; Samukawa, Y. Pharmacokinetics, Pharmacodynamics, and Safety of Luseogliflozin in Japanese Patients with Type 2 Diabetes Mellitus: A Randomized, Single-blind, Placebo-controlled Trial. Adv. Ther. 2015, 32, 319-340. [CrossRef] [PubMed] 
53. Takeuchi, T.; Dohi, K.; Omori, T.; Moriwaki, K.; Sato, Y.; Nakamori, S.; Fujimoto, N.; Fujii, E.; Yamada, N.; Ito, M. Diuretic effects of sodium-glucose cotransporter 2 inhibitor in patients with type 2 diabetes mellitus and heart failure. Int. J. Cardiol. 2015, 201, 1-3. [CrossRef] [PubMed]

54. Kawasoe, S.; Maruguchi, Y.; Kajiya, S.; Uenomachi, H.; Miyata, M.; Kawasoe, M.; Kubozono, T.; Ohishi, M. Mechanism of the blood pressure-lowering effect of sodium-glucose cotransporter 2 inhibitors in obese patients with type 2 diabetes. BMC Pharmacol. Toxicol. 2017, 18, 23. [CrossRef] [PubMed]

55. Klein, J.D.; Rash, A.; Sands, J.M.; Ecelbarger, C.M.; Tiwari, S. Candesartan Differentially Regulates Epithelial Sodium Channel in Cortex Versus Medulla of Streptozotocin-Induced Diabetic Rats. J. Epithel. Biol. Pharmacol. 2009, 2, 23. [CrossRef] [PubMed]

56. Song, J.; Knepper, M.A.; Verbalis, J.G.; Ecelbarger, C.A. Increased renal ENaC subunit and sodium transporter abundances in streptozotocin-induced type 1 diabetes. Am. J. Physiol. Ren. Physiol. 2003, 285, F1125-F1137. [CrossRef] [PubMed]

57. Kim, D.; Sands, J.M.; Klein, J.D. Changes in renal medullary transport proteins during uncontrolled diabetes mellitus in rats. Am. J. Physiol. Ren. Physiol. 2003, 285, F303-F309. [CrossRef]

58. Harris, R.C.; Brenner, B.M.; Seifter, J.L. Sodium-hydrogen exchange and glucose transport in renal microvillus membrane vesicles from rats with diabetes mellitus. J. Clin. Investig. 1986, 77, 724-733. [CrossRef]

59. Madala Halagappa, V.K.; Tiwari, S.; Riazi, S.; Hu, X.; Ecelbarger, C.M. Chronic candesartan alters expression and activity of NKCC2, NCC, and ENaC in the obese Zucker rat. Am. J. Physiol. Ren. Physiol. 2008, 294, F1222-F1231. [CrossRef]

60. Chavez-Canales, M.; Arroyo, J.P.; Ko, B.; Vazquez, N.; Bautista, R.; Castaneda-Bueno, M.; Bobadilla, N.A.; Hoover, R.S.; Gamba, G. Insulin increases the functional activity of the renal $\mathrm{NaCl}$ cotransporter. J. Hypertens. 2013, 31, 303-311. [CrossRef]

61. Layton, A.T.; Vallon, V.; Edwards, A. Predicted consequences of diabetes and SGLT inhibition on transport and oxygen consumption along a rat nephron. Am. J. Physiol. Ren. Physiol. 2016, 310, F1269-F1283. [CrossRef] [PubMed]

62. Pessoa, T.D.; Campos, L.C.; Carraro-Lacroix, L.; Girardi, A.C.; Malnic, G. Functional role of glucose metabolism, osmotic stress, and sodium-glucose cotransporter isoform-mediated transport on $\mathrm{Na}+/ \mathrm{H}+$ exchanger isoform 3 activity in the renal proximal tubule. J. Am. Soc. Nephrol. 2014, 25, 2028-2039. [CrossRef] [PubMed]

63. Fu, Y.; Gerasimova, M.; Mayoux, E.; Masuda, T.; Vallon, V. Acute and Chronic Cmplications. Diabetes 2014, 63, A103-A170. [CrossRef]

64. Novikov, A.; Vallon, V. Sodium glucose cotransporter 2 inhibition in the diabetic kidney: An update. Curr. Opin. Nephrol. Hypertens. 2016, 25, 50-58. [CrossRef] [PubMed]

65. Cassis, P.; Locatelli, M.; Cerullo, D.; Corna, D.; Buelli, S.; Zanchi, C.; Villa, S.; Morigi, M.; Remuzzi, G.; Benigni, A.; et al. SGLT2 inhibitor dapagliflozin limits podocyte damage in proteinuric nondiabetic nephropathy. JCI Insight 2018, 3. [CrossRef] [PubMed]

66. Takiyama, Y.; Sera, T.; Nakamura, M.; Ishizeki, K.; Saijo, Y.; Yanagimachi, T.; Maeda, M.; Bessho, R.; Takiyama, T.; Kitsunai, H.; et al. Impacts of Diabetes and an SGLT2 Inhibitor on the Glomerular Number and Volume in $\mathrm{db} / \mathrm{db}$ Mice, as Estimated by Synchrotron Radiation Micro-CT at SPring-8. EBioMedicine 2018, 36, 329-346. [CrossRef] [PubMed]

67. Vallon, V.; Gerasimova, M.; Rose, M.A.; Masuda, T.; Satriano, J.; Mayoux, E.; Koepsell, H.; Thomson, S.C.; Rieg, T. SGLT2 inhibitor empagliflozin reduces renal growth and albuminuria in proportion to hyperglycemia and prevents glomerular hyperfiltration in diabetic Akita mice. Am. J. Physiol. Ren. Physiol. 2014, 306, F194-F204. [CrossRef] [PubMed]

68. Nishiyama, A.; Kobori, H. Independent regulation of renin-angiotensin-aldosterone system in the kidney. Clin. Exp. Nephrol. 2018, 22, 1231-1239. [CrossRef]

69. Li, L.; Konishi, Y.; Morikawa, T.; Zhang, Y.; Kitabayashi, C.; Kobara, H.; Masaki, T.; Nakano, D.; Hitomi, H.; Kobori, H.; et al. Effect of a SGLT2 inhibitor on the systemic and intrarenal renin-angiotensin system in subtotally nephrectomized rats. J. Pharmacol. Sci. 2018, 137, 220-223. [CrossRef]

70. Kobori, H.; Navar, L.G. Urinary Angiotensinogen as a Novel Biomarker of Intrarenal Renin-Angiotensin System in Chronic Kidney Disease. Int. Rev. Thromb. 2011, 6, 108-116. 
71. Nijst, P.; Verbrugge, F.H.; Martens, P.; Bertrand, P.B.; Dupont, M.; Francis, G.S.; Tang, W.W.; Mullens, W. Plasma renin activity in patients with heart failure and reduced ejection fraction on optimal medical therapy. J. Renin Angiotensin Aldosterone Syst. 2017, 18, 1470320317729919. [CrossRef] [PubMed]

72. Kobori, H.; Harrison-Bernard, L.M.; Navar, L.G. Urinary excretion of angiotensinogen reflects intrarenal angiotensinogen production. Kidney Int. 2002, 61, 579-585. [CrossRef] [PubMed]

73. Satirapoj, B.; Siritaweesuk, N.; Supasyndh, O. Urinary angiotensinogen as a potential biomarker of diabetic nephropathy. Clin. Kidney J. 2014, 7, 354-360. [CrossRef] [PubMed]

74. Shin, S.J.; Chung, S.; Kim, S.J.; Lee, E.M.; Yoo, Y.H.; Kim, J.W.; Ahn, Y.B.; Kim, E.S.; Moon, S.D.; Kim, M.J.; et al. Effect of Sodium-Glucose Co-Transporter 2 Inhibitor, Dapagliflozin, on Renal Renin-Angiotensin System in an Animal Model of Type 2 Diabetes. PLoS ONE 2016, 11, e0165703. [CrossRef] [PubMed]

75. Yoshimoto, T.; Furuki, T.; Kobori, H.; Miyakawa, M.; Imachi, H.; Murao, K.; Nishiyama, A. Effects of sodium-glucose cotransporter 2 inhibitors on urinary excretion of intact and total angiotensinogen in patients with type 2 diabetes. J. Investig. Med. 2017, 65, 1057-1061. [CrossRef] [PubMed]

76. MORI, I.; ISHIZUKA, T. Effects of SGLT2 Inhibitors on Renin-Aldosterone System for One Month and Six Months in Type 2 Diabetes. Diabetes 2018, 67. [CrossRef]

77. Nomiyama, T.; Shimono, D.; Horikawa, T.; Fujimura, Y.; Ohsako, T.; Terawaki, Y.; Fukuda, T.; Motonaga, R.; Tanabe, M.; Yanase, T.; et al. Efficacy and safety of sodium-glucose cotransporter 2 inhibitor ipragliflozin on glycemic control and cardiovascular parameters in Japanese patients with type 2 diabetes mellitus; Fukuoka Study of Ipragliflozin (FUSION). Endocr. J. 2018, 65, 859-867. [CrossRef]

78. Lijnen, P.; Fagard, R.; Staessen, J.; Amery, A. Effect of chronic diuretic treatment on the plasma renin-angiotensin-aldosterone system in essential hypertension. Br. J. Clin. Pharmacol. 1981, 12, 387-392. [CrossRef]

79. Vaughan, E.D., Jr.; Carey, R.M.; Peach, M.J.; Ackerly, J.A.; Ayers, C.R. The renin response to diuretic therapyl A limitation of antihypertensive potential. Circ. Res. 1978, 42, 376-381. [CrossRef]

80. Komoroski, B.; Vachharajani, N.; Feng, Y.; Li, L.; Kornhauser, D.; Pfister, M. Dapagliflozin, a novel, selective SGLT2 inhibitor, improved glycemic control over 2 weeks in patients with type 2 diabetes mellitus. Clin. Pharmacol. Ther. 2009, 85, 513-519. [CrossRef]

81. Hollenberg, N.K.; Stevanovic, R.; Agarwal, A.; Lansang, M.C.; Price, D.A.; Laffel, L.M.; Williams, G.H.; Fisher, N.D. Plasma aldosterone concentration in the patient with diabetes mellitus. Kidney Int. 2004, 65, 1435-1439. [CrossRef] [PubMed]

82. Budoff, M.J.; Wilding, J.P.H. Effects of canagliflozin on cardiovascular risk factors in patients with type 2 diabetes mellitus. Int. J. Clin. Pract. 2017, 71. [CrossRef] [PubMed]

83. Pfeifer, M.; Townsend, R.R.; Davies, M.J.; Vijapurkar, U.; Ren, J. Effects of canagliflozin, a sodium glucose co-transporter 2 inhibitor, on blood pressure and markers of arterial stiffness in patients with type 2 diabetes mellitus: A post hoc analysis. Cardiovasc. Diabetol. 2017, 16, 29. [CrossRef] [PubMed]

84. Rahman, A.; Fujisawa, Y.; Nakano, D.; Hitomi, H.; Nishiyama, A. Effect of a selective SGLT2 inhibitor, luseogliflozin, on circadian rhythm of sympathetic nervous function and locomotor activities in metabolic syndrome rats. Clin. Exp. Pharmacol. Physiol. 2017, 44, 522-525. [CrossRef] [PubMed]

85. Wan, N.; Rahman, A.; Hitomi, H.; Nishiyama, A. The Effects of Sodium-Glucose Cotransporter 2 Inhibitors on Sympathetic Nervous Activity. Front. Endocrinol. (Lausanne) 2018, 9, 421. [CrossRef] [PubMed]

86. Matsusaka, T.; Niimura, F.; Shimizu, A.; Pastan, I.; Saito, A.; Kobori, H.; Nishiyama, A.; Ichikawa, I. Liver angiotensinogen is the primary source of renal angiotensin II. J. Am. Soc. Nephrol. 2012, 23, 1181-1189. [CrossRef] [PubMed]

87. Kobori, H.; Nishiyama, A.; Harrison-Bernard, L.M.; Navar, L.G. Urinary angiotensinogen as an indicator of intrarenal Angiotensin status in hypertension. Hypertension 2003, 41, 42-49. [CrossRef] [PubMed]

88. Wang, J.; Shibayama, Y.; Kobori, H.; Liu, Y.; Kobara, H.; Masaki, T.; Wang, Z.; Nishiyama, A. High glucose augments angiotensinogen in human renal proximal tubular cells through hepatocyte nuclear factor-5. PLoS ONE 2017, 12, e0185600. [CrossRef] [PubMed]

89. Fan, Y.Y.; Kobori, H.; Nakano, D.; Hitomi, H.; Mori, H.; Masaki, T.; Sun, Y.X.; Zhi, N.; Zhang, L.; Huang, W.; et al. Aberrant activation of the intrarenal renin-angiotensin system in the developing kidneys of type 2 diabetic rats. Horm. Metab. Res. 2013, 45, 338-343. [CrossRef]

90. Saito, T.; Urushihara, M.; Kotani, Y.; Kagami, S.; Kobori, H. Increased urinary angiotensinogen is precedent to increased urinary albumin in patients with type 1 diabetes. Am. J. Med. Sci. 2009, 338, 478-480. [CrossRef] 
91. Lee, M.J.; Kim, S.S.; Kim, I.J.; Song, S.H.; Kim, E.H.; Seo, J.Y.; Kim, J.H.; Kim, S.; Jeon, Y.K.; Kim, B.H.; et al. Changes in Urinary Angiotensinogen Associated with Deterioration of Kidney Function in Patients with Type 2 Diabetes Mellitus. J. Korean Med. Sci. 2017, 32, 782-788. [CrossRef] [PubMed]

92. Lei, L.; Nishiyama, A. A4490 Effects of esaxerenone (CS-3150), a non-steroidal selective of mineralocorticoid receptor antagonist, on blood pressure and renal injury in Dahl salt-sensitive rats. J. Hypertens. 2018, 36, e18. [CrossRef]

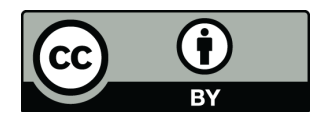

(C) 2019 by the authors. Licensee MDPI, Basel, Switzerland. This article is an open access article distributed under the terms and conditions of the Creative Commons Attribution (CC BY) license (http:/ / creativecommons.org/licenses/by/4.0/). 